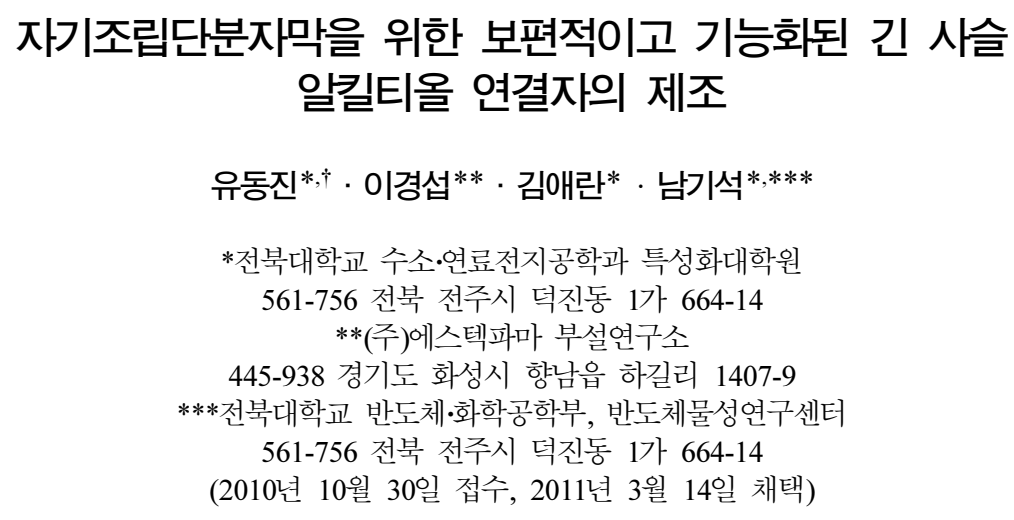

\title{
Preparations of Universal, Functionalized Long-Chain Alkylthiol Linkers for Self-assembled Monolayers
}

\author{
Dong Jin Yoo ${ }^{* \dagger}$, Kyong-Sub Lee**, Ae Rhan Kim* and Kee Suk Nahm*,*** \\ *Department of Hydrogen and Fuel Cells Engineering, Specialized Graduate School, \\ 664-14, 1 ga, Duckjin-dong, Duckjin-gu, Jeonju-si, Jeonbuk 561-756, Korea \\ **EstechPharma Co., Ltd., 1407-9 Hagil-ri, Hyangnam-eup, Hwaseong-si, Gyeonggi 445-922, Korea \\ ***School of Semiconductor and Chemical Engineering and Technology, and Semiconductor physics Research Center, \\ Chonbuk National University, 664-14, 1 ga, Duckjin-dong, Duckjin-gu, Jeonju-si, Jeonbuk 561-756, Korea \\ (Received 30 October 2010; accepted 14 March 2010)
}

\section{요 약}

본 연구에서는 자기조립단분자막(SAM)의 연구에 유용한 일련의 $\omega$-mercapto alkyl amine 1 및 $\omega$-mercapto alkanoic acid 2 를 만드는 제조공정을 서술하였다. 먼저 첫 번째 목표물질인 $\omega$-mercapto alkyl amine 1의 제조방법은 다음과 같 다: 먼저 시중에서 시판되는 potassium phthalimide와 $\omega$-bromo alcohol을 $80^{\circ} \mathrm{C}, \mathrm{DMF}$ 용매에서 치환반응으로 화합물 $\mathbf{3}$ 을 합성하였다. 아민기와 알코올기를 포함하는 화합물 $\mathbf{4}$ 을 합성하기 위하여 먼저 화합물 $\mathbf{3}$ 를 hydrazine hydrate로 환 류시킨 후, 이어서 c-HCl로 처리하여 부반응물 5를 수반하여 생성물 4를 76 98\% 수율로 만들었다. $\omega$-aminoakanol 4 의 hydroxyl기를 $\mathrm{HBr}$ 로 브로민화반응을 하여 $\omega$-bromoamine 화합물 6을 34 97\% 수율로 만들었다. 티올기를 도입하 기 위하여 화합물 6 을 $95 \%$ 에탄올 속에서 thiourea와 치환 반응하여 $\omega$-aminoalkanthiuronium 7 을 만든 다음, 이 화합 물을 센 염기 $(\mathrm{KOH})$ 와 센 산으로 처리하여 목표화합물, $\omega$-mercapto alkylamines 1 을 총 5 단계를 걸쳐서 제조하였다. 덧붙여 두 번째 목표물질인 $\omega$-mercapto alkanoic acid 2는 다음과 같이 2단계를 통하여 제조하였다: $\omega$-bromo alkanoic acid를 $95 \%$ 에탄올 속에서 thiourea로 처리하여 화합물 7을 만든 다음, 센 염기 $(\mathrm{KOH})$ 를 처리하여 thiuronium bromide 를 제거한 후, 다시 센 산 $(\mathrm{HCl})$ 수용액으로 처리하여 두 번째 목표화합물 $\omega$-mercapto alkanoic acid 2을 얻었다. 제조 한 긴 사슬 알킬티올 1 과 2 유도체들은 금속(Au, Pt, Ti)에 자기조립단분자 막을 형성함으로써 단백질, 효소 및 다양한 생체분자를 고정하는 연결자로 사용될 수 있으며, 그 밖에 금속의 표면개질을 이용하여 다양한 응용 연구를 위한 화학 도구로 사용될 수 있다.

\begin{abstract}
In this research, the preparation processes for making a series of $\omega$-mercapto alkylamine $\mathbf{1}$ and $\omega$-mercapto alkanoic acid 2 useful for studying of the self-assembled monolayer(SAM) are described. The preparation methods of the first goal materials, $\omega$-mercapto alkylamines $\mathbf{1}$ were carried out as follows: First, $\omega$-phthalimide alkanol $\mathbf{3}$ was synthesized from commercially available potassium phthalimide derivatives and $\omega$-bromoalkanol in $\mathrm{DMF}$ at $80^{\circ} \mathrm{C}$ via substitution reaction. After refluxing $\omega$-phthalimide alkanol $\mathbf{3}$ with hydrazine hydrate in ethanol followed by treating with c-HCl, $\omega$-aminoalkanol 4 was obtained in 76 98\% yield, accompanied with side-product 5 . Bromination of hydroxyl moiety of $\omega$-aminoalkanol 4 using aqueous hydrobromic acid furnished $\omega$-bromoamine 6 in 34 97\% yields. Substitution reaction 6 with thiourea in $95 \%$ ethanol gave $\omega$-aminoalkanthiuronium 7 , which was treated with aqueous
\end{abstract}

\footnotetext{
${ }^{\dagger}$ To whom correspondence should be addressed.

E-mail: djyoo@jbnu.ac.kr

\$이 논문은 전북대학교 김기주 교수님의 정년을 기념하여 투고되었습니다.
} 
strong base and aqueous strong sulfuric acid gave desired products, $\omega$-mercapto alkylamines 1 through overall 5 steps. The second target material, $\omega$-mercapto alkanoic acid 2 was prepared via 2 steps. $\omega$-bromo alkanoic acid was reacted with thiourea to give $\omega$-thiourea alkanoic acid 7 in $69-85 \%$, which was treated with aqueous strong base and strong acid to furnish $\omega$-mercapto alkanoic acid 2 in 50 98\%. The fabricated long-chain alkylthiol(LCAT) can be used as linkers to immobilize protein, enzyme and various kinds of biomolecules on the surface of metallic materials(Au, Pt, Ti) by SAM, and can be useful chemical tools for the application study on the surface modification of metallic materials.

Key words: SAM, Long-Chain Alkylthiol Linkers, Organic Material, Chemical Tools

\section{1. 서 론}

오늘날 자기조립단분자막(SAM)에 대한 연구는 유기 및 무기 나 노소재를 이용하는 첨단과학분야에서 가장 많이 연구하고 있다. 그 이유는 분자 표면의 과학적 연구와 기술적 탐구에 잘 정의된 구조적 특성을 제공하기 때문이다. 특히 선택된 작용기의 정밀한 배치를 조 절할 수 있는 능력은 생물의 표면과 막의 물리화학적 기능을 대체할 수 있는 의미에서 기질 결합 분자[1]로 사용될 수 있다. SAM는 여러 종류가 있으며, 티올 분자의 자발적인 화학흡착(chemisorptions)에 의해 이루어지는 $\mathrm{Au}$ 표면[2]에서 자기조립단분자막은 간단한 실험 시설을 사용하여 짧은 시간 내에 제조가 가능하며 완벽한 재현성을 가지고 있는 것으로 널리 알려져 있다. 티올 분자는 $\mathrm{Au}$ 표면에 식 (1) 에 나타낸 바와 같은 방법으로 결합[3]하며, 이때 만들어진 자기조립 단분자막은 분자간의 반데르발스 힘에 의해 매우 안정하다.

$$
\mathrm{Au}+\mathrm{HS}-\mathrm{R} \rightarrow \mathrm{Au}-\mathrm{S}-\mathrm{R}+\frac{1}{2} \mathrm{H}_{2}
$$

초기에 비가역적인 분자간 인력에 기초한 표면 및 계면에서의 산 -염기 반응 연구로부터 점차 가역적인 반응 연구로 발전하였다. 이러 한 연구는 간단한 구조를 가진 분자를 이용한 연구에서 더욱 발전하 여 특정한 거대고리 및 초분자의 크기 선택적인 분자 인식 기능 [3,4] 에 대한 연구로까지 진행되었다.

대부분의 효소나 생화학적 분자, 특히 항원, 항체들의 말단의 암모 늄기와 상호작용을 이용하여 단백질, 효소와 같은 생체물질의 고정 화 반응이나 단백질 단분자막의 제작에 이용되며 특정한 생화학 물 질의 인식에 필요한 생체 센서 및 각종 진단시약으로의 개발에 이용 될 수 있을 것이다. 단분자막은 유기 티올 말단기의 분자적 특성이 이차원의 넓은 평면에 나타나기 때문에 작용기의 특성, 계면에서의 분자간 인력에 관한 연구 등 기초 과학 적인 연구는 물론 분자간 인 력을 이용한 특정 분자에 선택성을 보이는 화학 및 바이오 센서의 개 발[5]과 같은 응용과학적 연구까지 최근에 세계적으로 집중적인 관 심을 받고 있는 연구분야이다.

이러한SAM 이용[6]의 장점은 첫째로 규칙적이며, 안정한 단분자 막을 쉽게 형성시킬 수 있다는 것이다. 둘째로 생성된 SAM 표면은 세포의 미소환경과 같은 막을 형성시킬 수 있으므로 생체물질의 고 정화에 적당하다. 셋째로 필요에 따라 여러 가지 작용기를 $\mathrm{SAM}$ 의 머리(head)로 사용하여 친수성과 소수성 표면의 설계가 용이하다. 넷 째로 SAM 위에 생체물질을 고정화하는데 생체물질이 미량이어도 가능하다는 점이다. 다섯째로 여러 가지 측정을 위하여 사용기간을 연장하여도 안정성을 오래 동안 유지할 수 있다. 마지막으로 표면 감 성기술을 사용하여 항원-항체 상호작용, DNA 혼성화 그리고 단백질 흡착 같은 분자 수준의 정보를 얻을 수 있다. 반면에 단점으로는 첫 째로 고정화된 효소들은 온도, 이온강도, $\mathrm{pH}$ 변화에 대하여 대단히 민감하므로 이들 조건들이 조금만 변하더라도 생체활성을 잃게 된다. 둘째로 SAM 중 어떤 것은 화학적 안정성이 좋지 않으므로 연구하
는 동안 산화될 수도 있다. 셋째로 단분자막의 전기장 유도와 열적 분해는 바이오 센서 제작에 어려움을 준다. 마지막으로 높은 표면 에 너지 때문에 소수성 SAM 표면은 여러 가지 오염물들이 쌓이게 되 므로 원치 않는 불순물이 흡수될 수 있고, 분석하려는 물질에 대한 인식자리가 차단될 수 있다는 단점들이 있다.

현재의 단백질 고정화 방법은 플라스틱과 같은 고체 지지체에 항 체를 흡착시키고 그 위에 그 항체와 상호작용을 하는 항원을 올리고 다시 그 위에 항체를 올려서 고정화시키는 방법이다. 분석 방법은 이 러한 항체에 조효소와 같은 enzyme 등을 사용하여 특정한 색깔이나 빛을 흡수하는 것으로부터 얼마나 단백질이 고정화되었는지 알아내 는 것이다. 하지만 이러한 방법은 항원을 붙일 때 어떠한 인력도 없이 그냥 표면에 흡착시키기 때문에 많은 양이 붙지 않으며, 붙는 것도 활성 부분의 반 정도가 아래로 가서 붙어 실질적으로 활성을 가진 단백질의 고정된 양이 줄어들게 된다. 이러한 배향성의 문제점을 해결하기 위해서 최근에 발표된 것이 아민 커플링법[7]이다. 이것은 금 표면에 티올기를 가진 카르복실기를 붙이고 이 카르복실기를 $N$-hydroxysuccinimide(NHS)와 1-ethyl-3-(3-dimethyl-aminopropyl) carbodiimide(EDCI)로 활성화시키면 30 40\%의 카르복실기가 반응 하여 좋은 N-hydroxysuccinimide ester로 변하여 단백질이나 다른 생 체 물질내의 아미노 그룹과 쉽게 결합하여 고정화시킬 수 있다.

금 $(\mathrm{Au})$ 표면 위에 alkanthiol들을 작용시켜 생성시킨 자기조립단 분자막은 적용성과 안정성 등 여러 가지 장점이 있기 때문에 바이오 센서의 기능성화와 규격성을 증가시킬 수 있는 유용한 표면으로 알 려졌다. 분자 층 안에 잘 알려진 수용체 분자를 함유시키고, 측정하 려는 물질과 host-guest 상호작용 복합체를 형성시켜 그 양을 측정할 수 있는 분자크기 수준으로 맞춤 표면을 만드는 지지대로 사용할 수 있다[8-12].

본 연구는 위에서 설명한 바와 같이 자기조립단분자막을 형성하

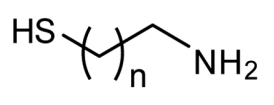

1

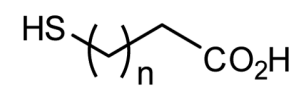

2
Fig. 1. Molecular structures of universal, long-chain alkylthiol(LCAT) linkers 1 and 2 functionalized by amine and carboxylic acid groups, respectively.

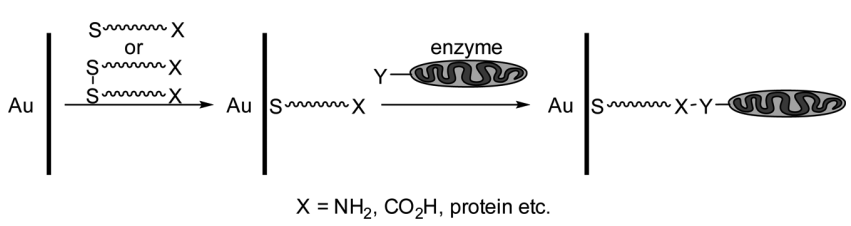

Fig. 2. Self-assembly of functionalized, thiolated monolayers on Au electrodes for the covalent linkage of enzyme. $X$ is a functional group for coupling with a protein. $Y$ is a complementary functional group to $\mathrm{X}$. 


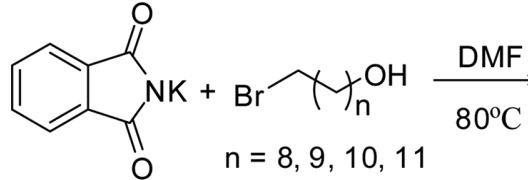
$\mathrm{n}=8,9,10,11$

$80^{\circ} \mathrm{C}$

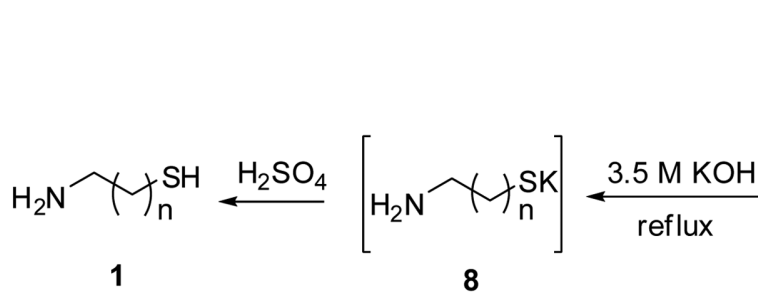

8<smiles>NC(=O)c1ccc(O)cc1</smiles><smiles>CC(C)(CN)COc1ccc2c(=O)[nH][nH]c(=O)c2c1</smiles>

4 5

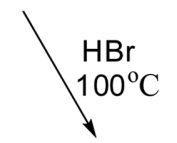<smiles>N=C(N)SCCN</smiles><smiles>CC(Br)(Br)CCCN</smiles>

Scheme 1. Preparation of $\omega$-mercapto alkylamine 1.

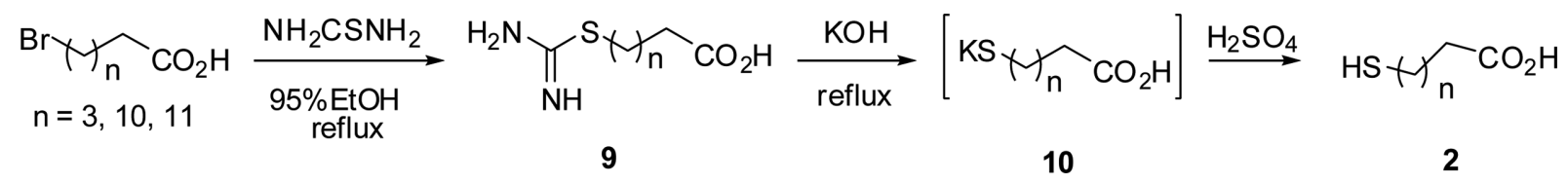

Scheme 2. Preparation of $\omega$-mercapto alkanoic acid 2.

여 여러 분야에 응용이 가능한 연결사슬의 길이를 변화시킨 일련의 화합물들을 제조하고자 한다. 이 연결자(linker)의 한쪽 머리(head)에 는 금속과 잘 결합되는 물질(thiol) 다른 쪽 꼬리(tail)에는 아민기나 카르복실산기가 각각 연결되어 있는 화합물 1 과 화합물 $\mathbf{2}$ 를 목표물 질(Fig. 1)로 선정하였다. 이러한 물질들은 연결자의 머리부분에는 $\mathrm{Au}, \mathrm{Pt}, \mathrm{Ti}$ 등의 금속에 결합할 수 있는 thiol(또는 silane)을 도입하고 다른 말단부위에 $\mathrm{NH}_{2}$ 나 $\mathrm{COOH}$ 를 가지고 있으므로, 말단부분과 상 보적인 기능기인 $\mathrm{COOH}$ 나 $\mathrm{NH}_{2}$ 를 각각 도입시키면 각종 생체 물질 과 강한 펩티드결합으로 인해서 단백질 및 효소 등이 직접 붙을 수 있는 환경을 제공하게 된다(Fig. 2). 궁극적으로 본 논문에서는 자기 조립단분자막 제조를 위해 한쪽 말단이 기능화된 긴 탄소사슬을 갖는 알킬티올 연결자, $\omega$-mercapto alkylamine(1)과 $\omega$-mercapto alkanoic acid(2)의 제조를 Scheme 1과 Scheme 2의 절차에 의해 수 행하여 각 단계의 반응공정을 정립한다.

\section{2. 실 험}

\section{2-1. 기기 및 시약}

반응에서 얻어진 생성물들의 구조분석을 위하여 다음과 같은 여 러가지 기기들을 사용하였다. 반응중에 생성물의 확인은 영린 M600D gas chromatography로 비교하여 확인하였다. 녹는점은 D.Y.S 0101 녹는점 측정장치로 측정하였다. ${ }^{1} \mathrm{H}$ 과 ${ }^{13} \mathrm{C} \mathrm{NMR} \mathrm{spectra는} \mathrm{JNM} \mathrm{EM-}$ $400 \mathrm{MHz}$ 를 사용하여 DMSO-d $6, \mathrm{CDCl}_{3}$ 와 $\mathrm{CD}_{3} \mathrm{OD}$ 용매를 사용하여 측정하였다. Proton chemical shift는 tetramethylsilane(TMS) 용매를 내부표준 물질로 사용하여 $\mathrm{ppm}$ 단위로 기록하였다. 짝지음상수 J는 $\operatorname{hertz}(\mathrm{Hz})$ 단위로 기록하였다. 얇은 막 크로마토그래피(TLC)는 E. Merck silica-gel 60F 254(0.2 mm precoated plate)를 사용하였으며, 전개된 TLC판은 UV나 $\mathrm{p}$-anisaldehyde 착색용액, $\mathrm{KMnO}_{4}$ 착색용액 으로 착색하여 태워봄으로써 분석하였다. 속성 컬럼크로마토그래피 (flash column chromatography)는 Merck silica-gel 60(230-400 mesh)을 사용하였다. 반응에 사용한 시약 및 일반용매, 즉, N,N-dimethyl-
formamide(DMF), N,N-dimethylsulfoxide(DMSO), ethanol(EtOH), methanol $(\mathrm{MeOH})$ 는 주로 Aldrich 제품을 정제 없이 사용하였거나, 경우에 따라서는 알려진 방법[14]으로 정제하여 사용하였다. 특별히 언급하지 않은 일반적인 작업용 용매는 삼전순약공업(주)의 화학제 품을 사용하였다.

\section{2-2. 일반적인 실험 방법}

실험 절차에서 다른 언급이 없는 대부분의 작업은 물과 포화소금 물(brine)으로 세척하고, 무수 $\mathrm{MaSO}_{4}$ 나 $\mathrm{NaSO}_{4}$ 로 건조시켜 거른 다 음 용매를 제거하였다. 또한 용매의 제거는 약 $15 ~ 20 \mathrm{mmHg}$ 의 압력 을 가진 Eyela A 아스피레이터와 Eyela N_N series 회전식 증류장 치를 사용하였다. 그리고 각종 분석기를 이용하여 분석하기 위한 시 료는 진공(vacuum pump) 라인을 이용하여 용매를 완전히 제거한 후 분석하였다.

\section{2-3. $\omega$-Mercapto alkyl amine(1)의 제조 \\ 2-3-1. $\omega$-Phthalimide alkanol(3)의 합성 \\ 2-3-1-1. Phthalimide nonanol(3a)}

건조한 $100 \mathrm{~mL}$ 플라스크에 potassium phthalimide(1.39 g, 7.2 $\mathrm{mmol})$ 와 9-bromo nonanol(1.37 g, $6.0 \mathrm{mmol})$ 을 건조한 $\mathrm{DMF}(15$ $\mathrm{mL}$ )로 용해시킨 후 $90 \sim 100{ }^{\circ} \mathrm{C}$ 에서 5 시간 반응시켰다. Ethyl acetate 로 묽힌 후, 증류수 $(30 \mathrm{~mL} \times 3)$ 와 포화소금물로 씻었다. 용액을 농축 시킨 후 실리카겔 컬럼크로마토그래피(hexane/ethyl acetate, 3:1)로 분리하여 $3 \mathrm{a}(1.66 \mathrm{~g}, 80 \%)$ 를 얻었다. $\mathbf{3 a}$ : $\mathrm{TLC}\left(\mathrm{R}_{f} 0.4\right.$, hexane/ethyl acetate, 2:1); m.p. $76 \sim 78{ }^{\circ} \mathrm{C}$; ${ }^{1} \mathrm{H} \mathrm{NMR}\left(400 \mathrm{MHz}, \mathrm{CDCl}_{3}\right) \delta 1.30 \sim 1.52$ (m, 10H), 1.55(q, 2H, $J=6.8 \mathrm{~Hz}), 1.67(\mathrm{q}, 2 \mathrm{H}, J=7.2 \mathrm{~Hz}), 3.62(\mathrm{t}, 2 \mathrm{H}$, $J=6.8 \mathrm{~Hz}), 3.67(\mathrm{t}, 2 \mathrm{H}, J=7.2 \mathrm{~Hz}), 7.13(\mathrm{~d}, 2 \mathrm{H}, J=2.8 \mathrm{~Hz}), 7.84(\mathrm{~d}, 2 \mathrm{H}$, $J=2.8 \mathrm{~Hz}) ;{ }^{13} \mathrm{C} \mathrm{NMR}\left(100 \mathrm{MHz}, \mathrm{CDCl}_{3}\right) \delta 25.61,26.75,28.52,29.00$, 29.23, 29.34, 32.72, 38.00, 63.01, 123.16, 132.14, 133.82, 168.48 .

2-3-1-2. Phthalimide decanol(3b)

건조시킨 $100 \mathrm{~mL}$ 플라스크에 potassium phthalimide $(2.5 \mathrm{~g}, 13.5$ 
$\mathrm{mmol})$ 와 10-bromodecanol(3.2 $\mathrm{g}, 13.5 \mathrm{mmol})$ 을 건조한 $\operatorname{DMF}(27$ $\mathrm{mL}$ )로 용해시킨 후 $85 \sim 90{ }^{\circ} \mathrm{C}$ 에서 5 시간 반응시켰다. 혼합물에 ethyl acetate을 가한 다음, 물 $(40 \mathrm{~mL} \times 3)$ 과 포화소금물 $(20 \mathrm{~mL})$ 로 씻은 후 $\mathrm{MgSO}_{4}$ 건조시켜 용액을 농축하였다. 혼합물을 실리카겔 컬럼크로마 토그래피(hexane/ethyl acetate, 3:1)로 분리한 다음, 재결정(hexane/ ethyl acetate, 7:1 용액)하여 $\mathbf{3 b}(3.47 \mathrm{~g}, 85 \%)$ 를 얻었다. $3 \mathbf{b}: \mathrm{TLC}\left(\mathrm{R}_{f}\right.$ 0.4 , hexane/ethyl acetate, 2:1); m.p. $66-68{ }^{\circ} \mathrm{C}$; ${ }^{1} \mathrm{H} \mathrm{NMR}(400 \mathrm{MHz}$, $\left.\mathrm{CDCl}_{3}\right) \delta 1.28 \sim 1.32(\mathrm{~m}, 12 \mathrm{H}), 1.52 \sim 1.68(\mathrm{~m}, 4 \mathrm{H}), 3.61 \sim 3.69(\mathrm{~m}, 4 \mathrm{H})$, 7.57(d, 2H), 7.84(d, 2H); $\left.{ }^{13} \mathrm{C} \mathrm{NMR(100} \mathrm{MHz,} \mathrm{CDCl}_{3}\right) \delta 25.64,26.78$, 28.53, 29.07, 29.29, 29.37, 29.40, 32.76, 38.04, 123.14, 132.16, 133.83, 168.49 .

\section{2-3-1-3. Phthalimide undecanol(3c)}

건조시킨 $100 \mathrm{~mL}$ 플라스크에 potassium phthalimide $(2.50 \mathrm{~g}, 13.5$ $\mathrm{mmol}$ 과 11-bromo undecanol(3.39 g, $13.5 \mathrm{mmol})$ 을 건조한 $\operatorname{DMF}(27$ $\mathrm{mL}$ )로 용해시킨 후 $85 \sim 90{ }^{\circ} \mathrm{C}$ 에서 5 시간 반응시켰다. 혼합물에 ethyl acetate을 가한 다음, 물 $(40 \mathrm{~mL} \times 3)$ 과 포화소금물 $(20 \mathrm{~mL})$ 로 씻은 후 $\mathrm{MgSO}_{4}$ 건조시켜 용액을 농축하여 실리카겔 컬럼크로마토그래피 (hexane/ethyl acetate, 3:1)로 분리하였다. 얻은 생성물을 hexane/ethyl acetate(7:1, v/v)혼합액으로 재결정(hexane/ethyl acetate, 7:1)하여 원 하는 $3 \mathbf{c}(3.56 \mathrm{~g}, 83 \%)$ 생성물을 얻었다. 3c: TLC( $\mathrm{R}_{f} 0.4$, hexane/ethyl acetate, 2:1); m.p. $52 \sim 54{ }^{\circ} \mathrm{C} ;{ }^{1} \mathrm{H} \operatorname{NMR}\left(300 \mathrm{MHz}, \mathrm{CDCl}_{3}\right) \delta 1.28(\mathrm{~m}$, $8 \mathrm{H}), 1.51 \sim 1.66(\mathrm{~m}, 6 \mathrm{H}), 3.59 \sim 3.67(\mathrm{~m}, 4 \mathrm{H}), 7.69(\mathrm{~d}, 2 \mathrm{H}, J=2.8 \mathrm{~Hz})$, 7.81(d, $2 \mathrm{H}, J=2.8 \mathrm{~Hz}) ;{ }^{13} \mathrm{C} \mathrm{NMR}\left(100 \mathrm{MHz}, \mathrm{CDCl}_{3}\right) \delta 25.70,26.83$, 28.58, 29.14, 29.36, 29.41, 29.42, 29.51, 32.81, 38.08, 63.11, 123.16, $132.18,133.84,168.50$.

2-3-1-4. 12-Phthalimide docacanol(3d)

건조시킨 $100 \mathrm{~mL}$ 플라스크에 potassium phthalimide $(2.50 \mathrm{~g}, 13.5$ $\mathrm{mmol}$ 과 12-bromo dodecanol(3.58 g, $13.5 \mathrm{mmol})$ 을 건조한 $\mathrm{DMF}(27$ $\mathrm{mL}$ 로 용해시킨 후 $85 \sim 90{ }^{\circ} \mathrm{C}$ 에서 4 시간 반응시켰다. Ethyl acetate 로 묽힌 후, 혼합물을 물 $(40 \mathrm{~mL} \times 3)$ 과 포화소금물 $(20 \mathrm{~mL})$ 을 사용하 여 세척하였다. $\mathrm{MgSO}_{4}$ 로 건조하고, 유기용매를 농축하여 실리카겔 컬럼크로마토그래피(hexane/ethyl acetate, 3:1)로 분리하였다. 얻은 생성물을 다시 재결정(hexane/ethyl acetate, 7:1)하여 $\mathbf{3 d}(4.10 \mathrm{~g}$, $92 \%)$ 를 얻었다. 3d: TLC $\left(\mathrm{R}_{f} 0.4\right.$, hexane/ethyl acetate, 2:1); m.p. 74$76{ }^{\circ} \mathrm{C} ;{ }^{1} \mathrm{H} \mathrm{NMR}\left(400 \mathrm{MHz}, \mathrm{CDCl}_{3}\right) \delta 1.25 \sim 1.52(\mathrm{~m}, 16 \mathrm{H}), 1.56(\mathrm{q}, 2 \mathrm{H}$ $J=6.8 \mathrm{~Hz}), 1.65(\mathrm{q}, 2 \mathrm{H}, J=7.2 \mathrm{~Hz}), 3.65(\mathrm{~m}, 4 \mathrm{H}, J=6.8 \mathrm{~Hz}), 7.08(\mathrm{~d}$, $2 \mathrm{H}, J=2.8 \mathrm{~Hz}), 7.83(\mathrm{~d}, 2 \mathrm{H}, J=2.8 \mathrm{~Hz}) ;{ }^{13} \mathrm{C} \mathrm{NMR}\left(100 \mathrm{MHz}, \mathrm{CDCl}_{3}\right) \delta$ $25.69,26.82,28.56,29.12,29.35,29.40,29.45,29.50,32.78,38.06$, $63.06,123.12,123.17,133.80,168.47$.

2-3-2. $\omega$-Amino alkanol 4제조

2-3-2-1. 9-Amino nonanol(4a)

$100 \mathrm{~mL}$ 플라스크에 phthalimide nonanol $3 \mathbf{a}(2.47 \mathrm{~g}, 8.54 \mathrm{mmol})$ 을 95\% EtOH에 용해시킨 후, $55 \%$ hydrazine hydrate $(0.48 \mathrm{~mL}, 8.54$ $\mathrm{mmol}$ )을 천천히 첨가하여 $80 \sim 85^{\circ} \mathrm{C}$ 에서 4 시간 반응시켰다. 실온 상태 에서 진한 염산을 첨가하여 $\mathrm{pH}$ 2가 되도록 하였다. 고체 phthalhydzide (5)를 유리 필터로 제거하면서 $95 \% \mathrm{EtOH}$ 로 세척하였 다. 용액을 농축한 후 $1 \mathrm{M} \mathrm{NaOH}$ 를 넣어서 $\mathrm{pH}$ 8 9로 조절하였다. Methylene chloride로 추출한 다음, 유기용매를 $\mathrm{MgSO}_{4}$ 로 건조시켜 농축한 다음 hexane으로 재결정하여 $\mathbf{4 a}(0.69 \mathrm{~g}, 76 \%)$ 를 얻었다. $\mathbf{4 a}$ : $\operatorname{TLC}\left(\mathrm{R}_{f}=0.1,10 \%\right.$ methanol/methylene chloride); m.p. $65 \sim 67{ }^{\circ} \mathrm{C} ;{ }^{1} \mathrm{H}$ $\operatorname{NMR}\left(400 \mathrm{MHz}, \mathrm{CDCl}_{3}\right) \delta 1.13 \sim 1.30(\mathrm{~m}, 10 \mathrm{H}), 1.43(\mathrm{q}, 2 \mathrm{H}, J=6.8 \mathrm{~Hz})$, 1.56(q, $2 \mathrm{H}, J=7.2 \mathrm{~Hz}), 2.67(\mathrm{t}, 2 \mathrm{H}, J=7.2 \mathrm{~Hz}), 3.36(\mathrm{t}, 2 \mathrm{H}, J=6.8 \mathrm{~Hz})$; ${ }^{13} \mathrm{C} \mathrm{NMR}\left(100 \mathrm{MHz}, \mathrm{CDCl}_{3}\right) \delta 25.71,26.82,29.33,29.36,29.52,32.77$, $33.68,42.14,62.83$.

\section{2-3-2-2. 10-Amino decanol(4b)}

$100 \mathrm{~mL}$ 플라스크에 phthalimide decanol $\mathbf{3 b}(3.35 \mathrm{~g}, 11.06 \mathrm{mmol})$ 을 95\% EtOH(22 mL)에 용해시킨 후 교반하면서 $55 \%$ hydrazine hydrate $(0.93 \mathrm{~g}, 16.04 \mathrm{mmol})$ 을 천천히 떨어뜨리고 $80^{\circ} \mathrm{C}$ 에서 4 시간 반응시 켰다. 실온에서 $\mathrm{pH}$ 1 2가 되도록 진한 염산 첨가하면 흰색고체가 생 성되었는데, 생성된 phthalhydzide(5)는 유리 필터로 제거하면서, $95 \% \mathrm{EtOH}$ 로 세척한 후 용매를 제거한 후 물 $(10 \mathrm{~mL})$ 와 $1 \mathrm{M} \mathrm{NaOH}$ 를 넣어 $\mathrm{pH}$ 8 9정도로 하였다. Methylene chloride로 추출하고 $\mathrm{MgSO}_{4}$ 로 건조시킨 후 농축하여 hexane으로 재결정하여 $\mathbf{4 b}(1.87 \mathrm{~g}, 98 \%)$ 를 얻었다. $4 \mathbf{b}: \operatorname{TLC}\left(\mathrm{R}_{f} 0.1,10 \%\right.$ methanol/methylene chloride); m.p. 63 64 ${ }^{\circ} \mathrm{C} ;{ }^{1} \mathrm{H}$ NMR(400 MHz, $\left.\mathrm{CDCl}_{3}\right) \delta 1.22 \sim 1.27(\mathrm{~m}, 12 \mathrm{H}), 1.54 \sim$ 1.60(m, 4H), 3.39(t, 2H), 3.69(t, 2H); ${ }^{13} \mathrm{C} \mathrm{NMR}\left(100 \mathrm{MHz}, \mathrm{CDCl}_{3}\right)$ $\delta 25.54,26.42,28.69,29.45,29.68,29.74,29.95,30.26,40.12,60.39$.

\section{2-3-2-3. 11-Amino undecanol(4c)}

$100 \mathrm{~mL}$ 플라스크에 phthalimide undecanol $3 \mathrm{c}(3.56 \mathrm{~g}, 11.20$ $\mathrm{mmol})$ 을 $95 \% \mathrm{EtOH}(30 \mathrm{~mL})$ 에 교반하면서 첨가하고 $55 \%$ hydrazine hydrate $(0.89 \mathrm{~mL}, 15.70 \mathrm{mmol})$ 을 천천히 떨어드리고 $80^{\circ} \mathrm{C}$ 에서 4 시 간 반응시켰다. 실온에서 $\mathrm{pH}$ 1 2가 되도록 진한 염산 첨가하여 흰 색고체가 생성되었는데, 생성된phthalhydzide(5)는 유리 필터로 제거 하면서, $95 \% \mathrm{EtOH}$ 로 세척한 다음 용매를 제거하여 물 $(10 \mathrm{~mL})$ 과 $1 \mathrm{M} \mathrm{NaOH}$ 를 넣어 $\mathrm{pH}$ 8 9 정도로 하였다. Methylene chloride로 추 출하고 $\mathrm{MgSO}_{4}$ 로 건조시킨 후 농축하여 hexane으로 재결정하여 $4 \mathrm{c}(1.66 \mathrm{~g}, 79 \%)$ 을 얻었다. $4 \mathrm{c}: \mathrm{TLC}\left(\mathrm{R}_{f} 0.1,10 \%\right.$ methanol/methylene chloride); m.p. $66-68{ }^{\circ} \mathrm{C} ;{ }^{1} \mathrm{H}$ NMR(400 MHz, $\left.\mathrm{CD}_{3} \mathrm{OD}\right) \delta 1.32 \sim 1.35$ $(\mathrm{m}, 14 \mathrm{H}), 1.51(\mathrm{q}, 2 \mathrm{H}, J=6.8 \mathrm{~Hz}), 1.60(\mathrm{q}, 2 \mathrm{H}, J=7.2 \mathrm{~Hz}), 2.83(\mathrm{t}, 2 \mathrm{H}$, $J=7.6 \mathrm{~Hz}), 3.53(\mathrm{t}, 2 \mathrm{H}) ;{ }^{13} \mathrm{C} \mathrm{NMR}\left(100 \mathrm{MHz}, \mathrm{CD}_{3} \mathrm{OD}\right) \delta 26.94,27.60$, $29.92,30.32,30.54,30.58,30.61,30.71,30.65,41.24,62.99$.

\section{2-3-2-4. 12-Amino dodecanol(4d)}

$100 \mathrm{~mL}$ 플라스크에 12-phthalimide docacanol $3 \mathbf{d}(3.88 \mathrm{~g}, 11.70$ $\mathrm{mmol})$ 을 $95 \% \mathrm{EtOH}$ 에 용해시키고 $55 \%$ hydrazinehydrate $(0.93 \mathrm{~mL}$, $16.4 \mathrm{mmol})$ 을 천천히 떨어뜨리고 $80{ }^{\circ} \mathrm{C}$ 에서 4 시간 환류시켰다. 실온 에서 고체 덩어리가 생성되어 $c-\mathrm{HCl}$ 을 가하여 $\mathrm{pH}$ 1 2 정도 조절하 였다. 미세한 고체 phthalhydzide(5)는 celite로 제거하면서 95\% $\mathrm{EtOH}$ 로 세척하였다. 유기용매를 농축한 후 물 $(10 \mathrm{~mL})$ 와 $1 \mathrm{M} \mathrm{NaOH}$ 로 $\mathrm{pH}$ 8-9로 조절하여 methylene chloride로 추출하였다. $\mathrm{MgSO}_{4}$ 로 건조한 다음 유기용매를 농축한 후 hexane으로 재결정하여 $\mathbf{4 d}(2.20 \mathrm{~g}$, $93 \%)$ 을 얻었다. $4 \mathrm{~d}$ : $\operatorname{TLC}\left(\mathrm{R}_{f} 0.1,10 \%\right.$ methanol/methylene chloride); m.p. 84 86 ${ }^{\circ} \mathrm{C} ;{ }^{1} \mathrm{H} \mathrm{NMR}\left(400 \mathrm{MHz}, \mathrm{CD}_{3} \mathrm{OD}\right) \delta 1.31 \sim 1.36(\mathrm{~m}, 16 \mathrm{H})$, 1.57 (q, 2H), 1.64(q, 2H, $J=7.2 \mathrm{~Hz}), 2.90(\mathrm{t}, 2 \mathrm{H}), 3.53(\mathrm{t}, 2 \mathrm{H}) ;{ }^{13} \mathrm{C}$ NMR (100 MHz, $\left.\mathrm{CD}_{3} \mathrm{OD}\right) \delta 26.95,27.45,28.59,30.22,30.48,30.59$, $30.61,30.66,30.72,33.65,40.78,62.99$.

2-3-3. $\omega$-Bromo alkylamine(6)의 제조

2-3-3-1. 9-Bromo nonanylamine(6a)

$100 \mathrm{~mL}$ 플라스크에 9-amino nonanol $4 \mathbf{a}(1.14 \mathrm{~g}, 7.14 \mathrm{mmol})$ 을 넣 고 $47 \%$ hydrobromonic acid $(5.50 \mathrm{~mL}, 22.80 \mathrm{mmol})$ 를 교반하면서 첨가하여 $100{ }^{\circ} \mathrm{C}$ 에서 10 시간 환류시켰다. 실온에서 아세톤 $(20 \mathrm{~mL})$ 을 첨가하고 냉장고에서 4시간 보관하였다. 생성된 고체를 유리 필 터를 사용하여 hexane/ethyl acetate(2:1, v/v)로 세척하면서 걸러서 
6a(1.07 g, $50 \%)$ 를 얻었다. 6a: TLC $\left(\mathrm{R}_{f} 0.4,10 \%\right.$ methanol/methylene chloride); m.p. $88 \sim 90{ }^{\circ} \mathrm{C} ;{ }^{1} \mathrm{H} \mathrm{NMR}\left(400 \mathrm{MHz}, \mathrm{CDCl}_{3}\right) \delta 1.25 \sim 1.31$ (m, 6H), 1.42 1.59(m, 4H), 1.78 1.85(m, 4H), 3.50(t, 2H), 3.41(t, $2 \mathrm{H}, J=6.8 \mathrm{~Hz}), 7.91(\mathrm{bs}, 2 \mathrm{H}) ;{ }^{13} \mathrm{C} \mathrm{NMR}\left(100 \mathrm{MHz}, \mathrm{CDCl}_{3}\right) \delta 26.48$, $27.42,28.05,28.58,28.80,29.12,32.71,33.95,40.21$.

2-3-3-2. 10-Bromo decanylamine(6b)

$100 \mathrm{~mL}$ 플라스크에 10-amino decanol $4 \mathrm{~b}(1.85 \mathrm{~g}, 10.70 \mathrm{mmol})$ 을 넣고 차가운 넣고 $47 \%$ hydrobromonic acid(12.4 g, $34.24 \mathrm{mmol})$ 을 교반하면서 첨가하여 $100{ }^{\circ} \mathrm{C}$ 에서 10 시간 환류시켰다. 실온에서 아세 톤 $(20 \mathrm{~mL})$ 을 첨가하고 냉장고에서 4시간 보관하였다. 생성된 고체 를 유리 필터를 사용하여 hexane/ethyl acetate(2:1)로 세척하면서 걸 러서 $6 \mathrm{~b}(1.14 \mathrm{~g}, 34 \%)$ 를 얻었다. $6 \mathrm{~b}: \mathrm{TLC}\left(\mathrm{R}_{f} 0.5,10 \%\right.$ methanol/ methylene chloride); m.p. $96 \sim 97{ }^{\circ} \mathrm{C}$; ${ }^{1} \mathrm{H}$ NMR $\left(400 \mathrm{MHz}, \mathrm{CDCl}_{3}\right) \delta$ $1.29 \sim 1.41(\mathrm{~m}, 12 \mathrm{H}), 1.72 \sim 1.85(\mathrm{~m}, 4 \mathrm{H}), 3.04(\mathrm{t}, 2 \mathrm{H}), 3.39(\mathrm{t}, 2 \mathrm{H}) ;{ }^{13} \mathrm{C}$ $\mathrm{NMR}\left(100 \mathrm{MHz}, \mathrm{CDCl}_{3}\right) \delta 26.67,27.64,18.16,28.76,29.03,29.43$, 29.50, 32.82, 34.05, 40.57 .

2-3-3-3. 11-Bromo undecanylamine $(\mathbf{6 c})$

$100 \mathrm{~mL}$ 플라스크에 11-amino undecanol $4 \mathbf{c}(1.54 \mathrm{~g}, 8.24 \mathrm{mmol})$ 을 넣고 $47 \%$ hydrobromonic acid $(6.4 \mathrm{~mL}, 26.37 \mathrm{mmol})$ 를 교반하면서 첨가하여 $100{ }^{\circ} \mathrm{C}$ 에서 8 시간 반응시켰다. 실온에서 아세톤 $(20 \mathrm{~mL})$ 첨 가하고 냉동실에서 12 시간 보관한 후 고체 결정을 유리 필터로 거른 다음, ethyl acetate로 재결정하여 $\mathbf{6 c}(2.65 \mathrm{~g}, 97 \%)$ 를 얻었다. $\mathbf{6 c}$ : $\mathrm{TLC}\left(\mathrm{R}_{f} 0.5,10 \%\right.$ methanol/methylene chloride); m.p. $106 \sim 108{ }^{\circ} \mathrm{C} ;{ }^{1} \mathrm{H}$ $\mathrm{NMR}\left(400 \mathrm{MHz}, \mathrm{CD}_{3} \mathrm{OD}\right) \delta 1.31 \sim 1.49(\mathrm{~m}, 14 \mathrm{H}), 1.64(\mathrm{q}, 2 \mathrm{H}), 1.81$ (q, $2 \mathrm{H}, J=6.8 \mathrm{~Hz}), 2.90(\mathrm{t}, 2 \mathrm{H}), 3.43(\mathrm{t}, 2 \mathrm{H}) ;{ }^{13} \mathrm{C} \mathrm{NMR}(100 \mathrm{MHz}$, $\left.\mathrm{CDCl}_{3}\right) \delta 27.44,28.59,29.14,29.82,30.20,30.44,30.50,30.52,33.98$, 34.42, 40.78.

2-3-3-4. 12-Bromo dodecanylamine(6d)

$100 \mathrm{~mL}$ 플라스크에 12-amino dodecanol $\mathbf{4 d}(2.22 \mathrm{~g}, 11.00 \mathrm{mmol})$ 를 넣고 $47 \%$ hydrobromonic $\operatorname{acid}(4.1 \mathrm{~mL}, 35.2 \mathrm{mmol}$ 를 교반하면 서 첨가하며 $100{ }^{\circ} \mathrm{C}$ 에서 8 시간 환류시켰다. 반응완료 후에 실온에서 고체가 생성되었으며 아세톤 $(10 \mathrm{~mL})$ 을 첨가하여 냉동실에서 4 시간 방치하였다. 생성된 고체를 유리 필터로 걸른 다음, 다시 재결정 (hexane/ethyl acetate, 5:1, v/v)하여 $\mathbf{6 d}(2.46 \mathrm{~g}, 65 \%$ )를 얻었다. $6 \mathbf{d}$ : $\mathrm{TLC}\left(\mathrm{R}_{f}\right.$ 0.5, 10\% methanol/methylene chloride); m.p. $140 \sim 142{ }^{\circ} \mathrm{C}$; ${ }^{1} \mathrm{H}$ NMR(400 MHz, CD $\left.\mathrm{OD}\right) \delta 1.27 \sim 1.39(\mathrm{~m}, 12 \mathrm{H}), 1.42 \sim 1.49(\mathrm{~m}, 4 \mathrm{H})$, $1.85 \sim 1.93(\mathrm{~m}, 4 \mathrm{H}), 3.02(\mathrm{t}, 2 \mathrm{H}), 3.41(\mathrm{t}, 2 \mathrm{H}) ;{ }^{13} \mathrm{C} \mathrm{NMR}\left(100 \mathrm{MHz}, \mathrm{CD}_{3} \mathrm{OD}\right)$ $\delta$ 26.51, 26.82, 27.42, 28.10, 28.66, 28.75, 28.88, 29.22, 29.26, 32.76, $39.99,40.19$.

2-3-4. $\omega$-Amino alkanthiuronium(7)의 제조

2-3-4-1. 9-Amino nonathiuronium(7a)

$100 \mathrm{~mL}$ 플라스크에 $95 \% \mathrm{EtOH}$ 에 thiourea $(0.28 \mathrm{~g}, 3.27 \mathrm{mmol})$ 을 용해시켜 $75 \sim 80^{\circ} \mathrm{C}$ 에서 3시간 환류시킨 다음, 9-bromo nonanylamine $\mathbf{6 a}(1.07 \mathrm{~g}, 3.54 \mathrm{mmol}$ 를 첨가하여 다시 4시간 환류시켰다. 용매를 농축시킨 후, 실리카겔 컬럼크로마토그래피(methanol/methylene chloride, $1: 5, \mathrm{v} / \mathrm{v})$ 로 분리하여 $7 \mathbf{a}(0.713 \mathrm{~g}, 92 \%)$ 를 얻었다. 7a: TLC $\left(\mathrm{R}_{f}\right.$ 0.1, $10 \%$ methanol/methylene chloride); ${ }^{1} \mathrm{H} \mathrm{NMR}(400 \mathrm{MHz}$, $\left.\mathrm{CD}_{3} \mathrm{OD}\right) \delta 0.69 \sim 1.01(\mathrm{~m}, 10 \mathrm{H}), 1.16 \sim 1.25(\mathrm{~m}, 4 \mathrm{H}), 2.46(\mathrm{t}, 2 \mathrm{H}, J=7.6 \mathrm{~Hz})$, 2.61(t, 2H); ${ }^{13} \mathrm{C} \mathrm{NMR}\left(100 \mathrm{MHz}, \mathrm{CD}_{3} \mathrm{OD}\right) \delta 27.26,28.35,29.21,29.52$, 29.77, 29.87, 30.03, 31.99, 40.78, 173.05 .

2-3-4-2. 10-Amino decanthiuronium(7b)
$100 \mathrm{~mL}$ 플라스크에 $95 \% \mathrm{EtOH}$ 에 thiourea $(0.33 \mathrm{~g}, 4.34 \mathrm{mmol})$ 를 $75 \sim 80^{\circ} \mathrm{C}$ 에서 3 시간 환류시킨 다음, 10-bromo decanylamine $6 \mathbf{b}(1.14 \mathrm{~g}$, $3.62 \mathrm{mmol}$ )을 넣어서 3시간 반응시켰다. 용매를 제거한 후, 농축하 여 재결정(hexane/ethyl acetate, $5: 1, \mathrm{v} / \mathrm{v})$ 하여 $7 \mathbf{b}(1.14 \mathrm{~g}, 80 \%)$ 를 얻 었다. 7b: $\operatorname{TLC}\left(\mathrm{R}_{f} 0.1,10 \%\right.$ methanol/methylene chloride); m.p. $100 \sim 102{ }^{\circ} \mathrm{C}$; ${ }^{1} \mathrm{H}$ NMR(400 MHz, $\left.\mathrm{CD}_{3} \mathrm{OD}\right) \delta 1.32 \sim 1.36(\mathrm{~m}, 10 \mathrm{H}), 1.63-$ 1.74(m, 4H), 2.91(t, 2H), 3.14(t, 2H); $\left.{ }^{13} \mathrm{C} \mathrm{NMR(100} \mathrm{MHz,} \mathrm{CD}_{3} \mathrm{OD}\right)$ $\delta 27.47,28.58,29.48,30.12,30.23,30.51,30.55,30.63,31.93,40.79$, 173.13 .

\section{2-3-4-3. 11-Amino undecanthiuronium(7c)}

$100 \mathrm{~mL}$ 플라스크에 $95 \% \mathrm{EtOH}$ 에 thiourea( $(0.49 \mathrm{~g}, 6.43 \mathrm{mmol})$ 을 용해시켜서 $80^{\circ} \mathrm{C}$ 에서 4 시간 반응시킨 다음, 다시 11-bromo undecanylamine $6 \mathbf{c}(1.76 \mathrm{~g}, 5.36 \mathrm{mmol})$ 을 넣어서 3시간 반응시켰다. 용매 를 제거한 후, 농축하여 재결정(hexane/ethyl acetate, $5: 1, \mathrm{v} / \mathrm{v}$ )하여 $7 \mathbf{c}(2.40 \mathrm{~g}, 99 \%)$ 를 얻었다. 7c: TLC $\left(\mathrm{R}_{f} 0.2,10 \%\right.$ methanol/methylene chloride); m.p. $98 \sim 100{ }^{\circ} \mathrm{C}$; ${ }^{1} \mathrm{H} \mathrm{NMR}\left(400 \mathrm{MHz}, \mathrm{CD}_{3} \mathrm{OD}\right) \delta 1.33 \sim 1.36$ (m, 14H), 1.63-1.74(m, 4H, $J=7.6 \mathrm{~Hz}), 2.91(\mathrm{t}, 2 \mathrm{H}, J=7.6 \mathrm{~Hz}), 3.14$ (t, 2H); ${ }^{13} \mathrm{C} \mathrm{NMR}\left(100 \mathrm{MHz}, \mathrm{CD}_{3} \mathrm{OD}\right) \delta 27.49,28.61,29.52,29.68$, $30.15,30.26,30.51,30.56,30.58,31.91,40.79,174.51$.

\section{2-3-4-4. 12-Amino dodecanthiuronium(7d)}

$100 \mathrm{~mL}$ 플라스크에 $95 \% \mathrm{EtOH}$ 에 thiourea $(0.36 \mathrm{~g}, 4.80 \mathrm{mmol})$ 을 용해시켜 $80 \sim 90{ }^{\circ} \mathrm{C}$ 에서 4 시간 환류시킨 다음, 12-bromo dodecanamine $\mathbf{6 d}(1.38 \mathrm{~g}, 4.00 \mathrm{mmol})$ 을 첨가하여 다시 5시간 환류한 후, 재결정 (hexane/ethyl acetate, $5: 1, \mathrm{v} / \mathrm{v}$ )하여 $7 \mathbf{d}(1.55 \mathrm{~g}, 92 \%$ )를 얻었다. 7d: $\operatorname{TLC}\left(\mathrm{R}_{f} 0.1,10 \%\right.$ methanol/methylene chloride); m.p. $116 \sim 118{ }^{\circ} \mathrm{C} ;{ }^{1} \mathrm{H}$ $\mathrm{NMR}\left(400 \mathrm{MHz}, \mathrm{CD}_{3} \mathrm{OD}\right) \delta 1.28 \sim 1.32(\mathrm{~m}, 14 \mathrm{H}), 1.45(\mathrm{q}, 2 \mathrm{H}), 1.66(\mathrm{~m}$, $4 \mathrm{H}, J=7.6 \mathrm{~Hz}), 2.90(\mathrm{t}, 2 \mathrm{H}), 3.03(\mathrm{t}, 2 \mathrm{H}) ;{ }^{13} \mathrm{C} \mathrm{NMR}\left(100 \mathrm{MHz}, \mathrm{CD}_{3} \mathrm{OD}\right)$ $\delta 27.49,28.60,29.53,29.67,30.15,30.21,30.55,30.58,30.66,31.90$, $40.79,173.14$.

2-3-5. $\omega$-Mercapto alkylamine(1)의 제조

2-3-5-1. 9-Mercapto nonanylamine(1a)

$100 \mathrm{~mL}$ 플라스크에 9-amino nonanthiuronium $7 \mathbf{a}(2.85 \mathrm{~g}, 7.51$ $\mathrm{mmol}$ )를 넣은 후 $3.56 \mathrm{M} \mathrm{KOH}$ 수용액 $(13.6 \mathrm{~mL})$ 을 넣고 $100 \sim 110^{\circ} \mathrm{C}$ 에서 8시간 환류시켰다. 반응 완료 후 실온 상태에서 $1 \mathrm{M} \mathrm{H}_{2} \mathrm{SO}_{4}$ 수 용액을 교반하면서 $\mathrm{pH}$ 1까지 과량을 첨가하였다. 용매에 용해되지 않은 disulfide물질을 유리 필터로 거른 후, 증류수와 $\mathrm{MeOH}$ 로 세척 하고 고체는 건조시켰다. 수용액은 methylene chloride 로 추출하고 $\mathrm{MgSO}_{4}$ 로 건조한 다음, 용액을 농축시켜 실리카겔 컬럼크로마토그 래피(10\% methanol/methylene chloride)로 분리하여 $\mathbf{1 a}(0.95 \mathrm{~g}, 72 \%)$ 를 얻었다. 1a: $\operatorname{TLC}\left(\mathrm{R}_{f} 0.6,10 \%\right.$ methanol/methylene chloride); m.p. $186 \sim 187{ }^{\circ} \mathrm{C} ;{ }^{1} \mathrm{H}$ NMR(400 MHz, CD $\left.\mathrm{CD}_{3} \mathrm{OD}\right) \delta 1.38 \sim 1.44(\mathrm{~m}, 10 \mathrm{H}), 1.56 \sim$ 1.62(m, 4H), 2.56(t, 2H), 2.81(t, 2H); ${ }^{13} \mathrm{C} \mathrm{NMR}\left(100 \mathrm{MHz}, \mathrm{CDCl}_{3}\right)$ $\delta 25.93,27.48,28.92,29.67,30.01,30.34,34.44,34.57,42.39$; IR (film) $2917,2843,2659,1625,1466,1196,730,514 \mathrm{~cm}^{-1}$.

2-3-5-2. 10-Mercapto decanylamine(1b)

$100 \mathrm{~mL}$ 플라스크에 10-amino undecanthiuronium $7 \mathbf{b}(1.14 \mathrm{~g}, 2.89$ $\mathrm{mmol}$ ) $85 \% \mathrm{KOH}$ 을 수용액 상태 $3.56 \mathrm{M}$ 로 만들어 $10 \mathrm{~mL}$ 넣어서 $100 \sim 110^{\circ} \mathrm{C}$ 에서 12 시간 반응시켰다. 다시 실온 상태로 식힌 후에 교 반하면서 $1 \mathrm{M} \mathrm{H}_{2} \mathrm{SO}_{4}$ 를 $\mathrm{pH}$ 1이 되게 첨가하여 10 분간 교반 후에 용 매에 용해되지 않은 disulfide 물질을 유리 필터로 거른 후, 증류수와 $\mathrm{MeOH}$ 로 세척하고 고체는 건조시켰다. 용액은 농축시킨 후 
methylene chloride로 추출하여 유기용매를 $\mathrm{MgSO}_{4}$ 로 건조하여 농축 한 후, hexane으로 재결정하여 $\mathbf{1 b}(0.12 \mathrm{~g}, 52 \%)$ 를 얻었다. $\mathbf{1 b}$ : TLC ( $\mathrm{R}_{f} 0.6,10 \%$ methanol/methylene chloride); ${ }^{1} \mathrm{H} \mathrm{NMR}\left(400 \mathrm{MHz}, \mathrm{CD}_{3} \mathrm{OD}\right)$ $\delta 1.28 \sim 1.30(\mathrm{~m}, 12 \mathrm{H}), 1.54 \sim 1.62(\mathrm{~m} .4 \mathrm{H}), 2.48(\mathrm{t}, 2 \mathrm{H}), 3.07(\mathrm{t}, 2 \mathrm{H}) ;{ }^{13} \mathrm{C}$ $\mathrm{NMR}\left(100 \mathrm{MHz}, \mathrm{CD}_{3} \mathrm{OD}\right) \delta 24.97,27.93,29.42,30.22,30.48,30.66$, 30.70, 31.19, 35.25, 43.28.

\section{2-3-5-3. 11-Mercapto undecanylamine(1c)}

$100 \mathrm{~mL}$ 플라스크에 11-amino undecanthiuronium $7 \mathbf{c}(2.00 \mathrm{~g}, 5.32$ $\mathrm{mmol}$ )에 $85 \% \mathrm{KOH}$ 을 수용액 상태 $3.56 \mathrm{M}$ 로 만들어 $10 \mathrm{~mL}$ 넣어서 $100 \sim 110^{\circ} \mathrm{C}$ 에서 12 시간 반응시켰다. 다시 실온상태로 식힌 후에 교 반하면서 $1 \mathrm{M} \mathrm{H}_{2} \mathrm{SO}_{4}$ 를 $\mathrm{pH}$ 1이 되게 첨가하여 10 분간 교반 후에 유 기 층과 수용액 층에 녹지 않은 물질을 거른다음, 증류수, $\mathrm{MeOH}$ 로 씻어주었고 disulfide 고체는 건조시켰다. 나머지 용액은 농축시킨 다 음, methylene chloride로 추출하여 유기용매를 $\mathrm{MgSO}_{4}$ 로 건조하여 농축한 후, hexane으로 재결정하여 $\mathbf{1 c}(0.87 \mathrm{~g}, 80 \%)$ 를 얻었다. 1c: $\mathrm{TLC}\left(\mathrm{R}_{f}\right.$ 0.6, $10 \%$ methanol/methylene chloride); m.p. 191 192 ${ }^{\circ} \mathrm{C}$; ${ }^{1} \mathrm{H} \operatorname{NMR}\left(400 \mathrm{MHz}, \mathrm{CD}_{3} \mathrm{OD}\right) \delta 1.31 \sim 1.42(\mathrm{~m}, 14 \mathrm{H}), 1.56(\mathrm{q}, 2 \mathrm{H}, J=$ $7.2 \mathrm{~Hz}), 1.62(\mathrm{q}, 2 \mathrm{H}, J=6.8 \mathrm{~Hz}), 2.48(\mathrm{t}, 2 \mathrm{H}), 2.91(\mathrm{t}, 2 \mathrm{H}) ;{ }^{13} \mathrm{C} \mathrm{NMR}$ $\left(100 \mathrm{MHz}, \mathrm{CD}_{3} \mathrm{OD}\right) \delta 24.98,27.42,29.34,29.39,30.15,30.26,30.41$, $30.43,30.51,30.55,35.14$.

2-3-5-4. 12-Mercapto dodecanylamine(1d)

$100 \mathrm{~mL}$ 플라스크에 12-amino dodecanthiuronium $7 \mathbf{d}(2.50 \mathrm{~g}, 5.92$ $\mathrm{mmol}$ 를 넣고 $85 \% \mathrm{KOH}$ 를 수용액 $3.56 \mathrm{M}$ 농도로 하여 $10 \mathrm{~mL}$ 넣 어서 $100 \sim 110^{\circ} \mathrm{C}$ 에서 8 시간 환류시켰다. 온도를 실온으로 식힌 후 1 $\mathrm{M} \mathrm{H}_{2} \mathrm{SO}_{4}$ 를 $\mathrm{pH}$ 1까지 되게 첨가한 후 10 분간 교반하였다. 고체를 유리 필터로 거르고 증류수로 세척하여 걸른 고체를 다시 $\mathrm{MeOH}$ 로 용해시켰고 disulfide고체는 건조하였다. 용액은 농축시킨 후 methylene chloride로 추출하여 일련의 과정을 거쳐 얻을 고체를 다 시 hexane으로 재결정하여 $\mathbf{1 d}(0.98 \mathrm{~g}, 76 \%)$ 를 얻었다. $\mathbf{1 d}$ : TLC $\left(\mathrm{R}_{f}\right.$ 0.6, 10\% methanol/methylene chloride); m.p. $210-211{ }^{\circ} \mathrm{C}$; ${ }^{1} \mathrm{H}$ NMR (400 MHz, CD $\left.{ }_{3} \mathrm{OD}\right) \delta 1.29 \sim 1.40(\mathrm{~m}, 16 \mathrm{H}), 1.51 \sim 1.59(\mathrm{~m} .4 \mathrm{H}), 2.49(\mathrm{t}$, $2 \mathrm{H}), 2.68(\mathrm{t}, 2 \mathrm{H}, J=7.2 \mathrm{~Hz}) ;{ }^{13} \mathrm{C} \mathrm{NMR}\left(100 \mathrm{MHz}, \mathrm{CD}_{3} \mathrm{OD}\right) \delta 27.86$, $28.51,29.43,30.20,30.31,30.51,30.62,30.68,30.72,31.41,32.03$, $32.03,39.82$.

\section{2-4. $\omega$-Mercapto alkanoic $\operatorname{acid(2)}$ 의 제조}

2-4-1. Thiourea alkanoic $\operatorname{acid}(\mathbf{8})$ 의 합성

2-4-1-1. 5-Thiourea pantanoic acid(8a)

$100 \mathrm{~mL}$ 플라스크에 $95 \% \mathrm{EtOH}$ 로 thiourea( $0.66 \mathrm{~g}, 8.70 \mathrm{mmol})$ 을 용해시켜 $75 \sim 80^{\circ} \mathrm{C}$ 에서 4 시간 환류시킨 후 5-bromo valeric acid( $1.50 \mathrm{~g}$, $8.29 \mathrm{mmol}$ 를 첨가하고 4시간 더 환류시켰다. 용매를 농축시킨 후, 실리카겔 컬럼크로마토그래피( $10 \%$ methanol/methylene chloride)로 분리하여 $8 \mathbf{a}(1.14 \mathrm{~g}, 83 \%)$ 를 얻었다. 8a: TLC $\left(\mathrm{R}_{f} 0.6,10 \%\right.$ methanol/ methylene chloride); ${ }^{1} \mathrm{H} \mathrm{NMR}\left(400 \mathrm{MHz}, \mathrm{CD}_{3} \mathrm{OD}\right) \delta 1.74 \sim 1.85(\mathrm{~m}$, $4 \mathrm{H}), 2.36\left(\mathrm{t}, 2 \mathrm{H}\right.$ ), 3.31(t, 2H,); ${ }^{13} \mathrm{C} \mathrm{NMR}\left(100 \mathrm{MHz}, \mathrm{CD}_{3} \mathrm{OD}\right) \delta 24.72$, 29.16, 31.55, 34.06, 172.94, 176.93.

2-4-1-2. 11-Thiourea undecanoic $\operatorname{acid}(\mathbf{8 b})$

$100 \mathrm{~mL}$ 플라스크에 $95 \% \mathrm{EtOH}(16 \mathrm{~mL})$ 로 thiourea(1.15 g, 15.0 $\mathrm{mmol}$ )을 용해시킨 후 $75 \sim 80{ }^{\circ} \mathrm{C}$ 에서 3 시간 환류시켰다. 다시 11bromo undecanoic acid(2.00 g, $7.54 \mathrm{mmol})$ 을 첨가하여 4시간 환류 시켰다. 용액을 농축시킨 후 실리카겔 컬럼크로마토그래피 $(10 \%$ methanol/methylene chloride)로 분리하였다. 얻은 고체를 다시 재결 정(hexane/ethyl acetate, $5: 1, \mathrm{v} / \mathrm{v}$ )하여 $\mathbf{8 b}(1.36 \mathrm{~g}, 69 \%$ )를 얻었다. $\mathbf{8 b}$ : $\mathrm{TLC}\left(\mathrm{R}_{f} 0.2,10 \%\right.$ methanol/methylene chloride); m.p. $46 \sim 47{ }^{\circ} \mathrm{C} ;{ }^{1} \mathrm{H}$ $\mathrm{NMR}\left(400 \mathrm{MHz}, \mathrm{CD}_{3} \mathrm{OD}\right) \delta 1.23-1.30(\mathrm{~m}, 10 \mathrm{H}), 1.44(\mathrm{q}, 2 \mathrm{H}), 1.60(\mathrm{q}$, $2 \mathrm{H} J=7.2 \mathrm{~Hz}), 1.72(\mathrm{q}, 2 \mathrm{H}, J=7.2 \mathrm{~Hz}), 2.28(\mathrm{t}, 2 \mathrm{H}),, 3.12(\mathrm{t}, 2 \mathrm{H}) ;{ }^{13} \mathrm{C}$ $\mathrm{NMR}\left(100 \mathrm{MHz}, \mathrm{CD}_{3} \mathrm{OD}\right) \delta 25.70,29.13,29.21,29.70,29.85,29.98$, $30.06,31.60,34.75,172.70,177.46$.

2-4-1-3. 12-Thiourea dodecanoic $\operatorname{acid}(\mathbf{8 c})$

$100 \mathrm{~mL}$ 플라스크에 $95 \% \mathrm{EtOH}(10 \mathrm{~mL})$ 로 thiourea $(0.98 \mathrm{~g}, 12.90$ $\mathrm{mmol}$ )를 용해시켜 $75 \sim 80{ }^{\circ} \mathrm{C}$ 에서 4시간 동안 환류시킨 후, 12-bromo dodecanoic acid(3.0 g, $10.74 \mathrm{mmol}$ 를 첨가한 후 4시간 더 환류시켰다. 용액을 농축시킨 후 실리카겔 컬럼크로마토그래피 $(10 \%$ methanol/ methylene chloride)로 분리하였다. 얻은 고체를 다시 재결정 (hexane/ ethyl acetate, $5: 1, \mathrm{v} / \mathrm{v})$ 하여 $\mathbf{8 c}(2.51 \mathrm{~g}, 85 \%)$ 를 얻었다. 8c: TLC $\left(\mathrm{R}_{f}\right.$ $0.2,10 \%$ methanol $/$ methylene chloride); m.p. $82 \sim 83{ }^{\circ} \mathrm{C} ;{ }^{1} \mathrm{H}$ NMR (400 MHz, CD 3 OD) $\delta 1.26 \sim 1.38(\mathrm{~m}, 14 \mathrm{H}), 1.45(\mathrm{q}, 2 \mathrm{H}) 1.58(\mathrm{q}, 2 \mathrm{H})$, 1.71(t, $2 \mathrm{H} J=7.2 \mathrm{~Hz}), 2.27(\mathrm{t}, 2 \mathrm{H}) ;{ }^{13} \mathrm{C} \mathrm{NMR}\left(100 \mathrm{MHz}, \mathrm{CD}_{3} \mathrm{OD}\right)$ $\delta 26.07,29.43,29.66,30.06,30.21,30.39,30.47,30.52,31.88,34.92$, $173.10,177.87$.

2-4-2. $\omega$-Mercapto alkanoic acid(2)의 제조

2-4-2-1. 5-Mercapto pantanoic acid(2a)

$100 \mathrm{~mL}$ 플라스크에 5-thiourea pantanoic acid $8 \mathbf{a}(1.14 \mathrm{~g}, 6.87$ $\mathrm{mmol})$ 을 $3.56 \mathrm{M} \mathrm{KOH}$ 수용액 $(14 \mathrm{~mL})$ 에 용해시켜 $100 \sim 110^{\circ} \mathrm{C}$ 에서 4시간 환류시켰다. 반응 완료 후 실온에서 methylene chloride에 녹 인 다음, 교반하면서 $\mathrm{pH}$ 1이 될 때까지 과량 $1 \mathrm{M} \mathrm{H}_{2} \mathrm{SO}_{4}$ 를 천천히 첨가하였다. 유기 층을 다시 증류수로 2 번 세척하고 $\mathrm{MgSO}_{4}$ 로 건조 시킨 후 농축하였다. 혼합물을 실리카겔 컬럼크로마토그래피 $(5 \%$ methanol/methylene chloride)로 분리하여 순수한 $\mathbf{2 a}(0.46 \mathrm{~g}, 50 \%)$ 를 얻었다. 2a: $\operatorname{TLC}\left(\mathrm{R}_{f} 0.6,10 \%\right.$ methanol/methylene chloride); ${ }^{1} \mathrm{H}$ $\operatorname{NMR}\left(400 \mathrm{MHz}, \mathrm{CD}_{3} \mathrm{OD}\right) \delta 1.36 \sim 1.63(\mathrm{~m}, 4 \mathrm{H}), 2.20(\mathrm{t}, 2 \mathrm{H}), 2.41(\mathrm{t}$, $2 \mathrm{H}, J=6.8 \mathrm{~Hz}) ;{ }^{13} \mathrm{C} \mathrm{NMR}\left(100 \mathrm{MHz}, \mathrm{CD}_{3} \mathrm{OD}\right) \delta 24.72,29.65,31.72$, $34.38,177.40$.

2-4-2-2. 11-Mercapto undecanoic $\operatorname{acid}(\mathbf{2 b})$

$100 \mathrm{~mL}$ 플라스크에 11-thiourea undecanoic acid $8 \mathbf{b}(1.54 \mathrm{~g}, 3.91$ $\mathrm{mmol})$ 를 $\mathrm{KOH}$ 수용액 $(20 \mathrm{~mL})$ 에 용해시킨 후, $100 ~ 110^{\circ} \mathrm{C}$ 에서 5 시 간 환류시켰다. 반응 완료 후 실온에서 methylene chloride에 녹인 다 음, 교반하면서 $\mathrm{pH} 1$ 정도될 때까지 과량 $1 \mathrm{M} \mathrm{H}_{2} \mathrm{SO}_{4}$ 수용액을 첨가 하였다. 유기층을 증류수로 2 번 세척하고 $\mathrm{MgSO}_{4}$ 로 건조시킨 후 농 축하였다. 혼합물을 실리카겔 컬럼크로마토그래피(5\% methanol/ methylene chloride)로 분리하고 다시 재결정(hexane/ethyl acetate, $5: 1, \mathrm{v} / \mathrm{v})$ 하여 $2 \mathbf{b}(0.48 \mathrm{~g}, 65 \%)$ 를 얻었다. $\mathbf{2 b}$ : $\mathrm{TLC}\left(\mathrm{R}_{f} 0.6,10 \%\right.$ methanol/methylene chloride); m.p. 90 91 ${ }^{\circ} \mathrm{C} ;{ }^{1} \mathrm{H} \mathrm{NMR}(400 \mathrm{MHz}$, DMSO-d $\left._{6}\right) \delta 1.24 \sim 1.29(\mathrm{~m}, 12 \mathrm{H}), 1.47(\mathrm{q}, 2 \mathrm{H}), 1.60(\mathrm{q}, 2 \mathrm{H}), 1.93(\mathrm{t}$, $2 \mathrm{H}), 2.68(\mathrm{t}, 2 \mathrm{H}, J=7.2 \mathrm{~Hz}) ;{ }^{13} \mathrm{C} \mathrm{NMR}\left(100 \mathrm{MHz}, \mathrm{DMSO}_{6}\right) \delta 22.05$, 24.51, 2768, 28.27, 28.39, 28.54, 28.72, 28.83, 33.72, 33.83, 174.49; IR (film) 3039, 2917, 2851, 2614, 1691, 1470, 1290, 1204, 939, 604, $518 \mathrm{~cm}^{-1}$.

2-4-2-3. 12-Mercapto dodecanoic acid(2c)

$100 \mathrm{~mL}$ 플라스크에 12-thiourea dodecanoic acid $8 \mathbf{c}(2.50 \mathrm{~g}, 9.08$ $\mathrm{mmol})$ 을 $0.55 \mathrm{M} \mathrm{KOH}$ 수용액 $(18 \mathrm{~mL})$ 을 넣고 $100 \sim 110^{\circ} \mathrm{C}$ 에서 4 시 간 환류시켰다. 반응완료 후 실온에서 플라스크에 methylene chloride 
에 녹인 다음, 교반하면서 $1 \mathrm{M} \mathrm{H}_{2} \mathrm{SO}_{4}$ 를 천천히 첨가하였다. 유기층 을 증류수로 2 번 세척하고 $\mathrm{MgSO}_{4}$ 로 건조시킨 후 농축하였다. 혼합 물을 실리카겔 컬럼크로마토그래피(5\% methanol/methylene chloride) 로 분리 후, 다시 재결정 (hexane/ethyl acetate, $5: 1, \mathrm{v} / \mathrm{v}$ )하여 $\mathbf{2 c}(2.07 \mathrm{~g}$, $98 \%)$ 를 얻었다. $2 \mathrm{c}: \mathrm{TLC}\left(\mathrm{R}_{f} 0.6,10 \%\right.$ methanol/methylene chloride); m.p. 84 85 ${ }^{\circ} \mathrm{C}$; ${ }^{1} \mathrm{H}$ NMR(400 MHz, DMSO-d $\left.\mathrm{d}_{6}\right) \delta 1.20 \sim 1.37(\mathrm{~m}, 14 \mathrm{H})$, $1.45(\mathrm{q}, 2 \mathrm{H}), 1.60(\mathrm{q}, 2 \mathrm{H}, J=7.2 \mathrm{~Hz}), 2.17(\mathrm{t}, 2 \mathrm{H}, J=7.2 \mathrm{~Hz}), 2.63(\mathrm{t}, 2 \mathrm{H})$ ${ }^{13} \mathrm{C}$ NMR(100 MHz, DMSO-d 6 ) $\delta 24.47,27.68,28.49,28.53,28.79$, 28.87, 28.89, 33.62, 37.87, 174.47 .

\section{3. 결과 및 고찰}

\section{3-1. $\omega$-Mercapto alkylamine(1)의 제조}

먼저 시중에서 시판되는 potassium phthalimide을 DMF 용매에 녹 인 다음, bromoalcohol을 가하여 치환반응으로 화합물 3을 80 92\% 수율로 얻었다. 이 과정에서 $\mathrm{DMF}$ 는 보통의 회전식증류장치로 제거 하기 힘들어 첨가한 $\mathrm{DMF}$ 양에 7 10배에 달하는 증류수를 가하여 서 너차례에 걸처 나누어 씻어줌으로써 $90 \%$ 정도의 $\mathrm{DMF}$ 를 제거하였 으며, 잔량의 용매는 진공펌프를 회전식증류장치에 연결하여 제거하 였다. ${ }^{1} \mathrm{H} \mathrm{NMR}$ 스펙트럼 데이타에서 phthalimide의 방향족수소는 7.7 7.8 ppm에서 확인하였고, 메틸렌그룹의 $-\mathrm{CH}_{2}$-는 $1.3 \sim 1.6 \mathrm{ppm}$ 의 피크로 생성물을 확인하였다. 아민기와 알콜기를 포함하는 화합물 $\mathbf{4}$ 을 합성하기 위하여 먼저 화합물 3을 hydrazine hydrate넣어[14] 환 류시킨 후, c-HCl로 처리하고 부반응물 $\mathbf{5}$ 을 유리 필터를 사용하여 95\% EtOH로 씻어주면서 제거하였다. 이 생성물을 실리카겔 컬럼크 로마토그래피로 분리하면 원하는 생성물이 실리카겔에 흡착되기 때 문에 수율이 떨어지게 됨으로, 재결정방법으로 생성물 6을 76 98\% 수율로 얻었다. ${ }^{1} \mathrm{H}$ NMR 스펙트럼 데이타에서 phthalimide에 해당 하는 7 8 ppm의 피크가 없어졌으며 $2.6 \mathrm{ppm}\left(\mathrm{NH}_{2} \mathrm{CH}_{2}-\right)$ 의 피크가 생성되어 원하는 생성물질임을 확인하였다. 이어서 생성물 $\mathbf{4}$ 에 $\mathrm{HBr}$ 를 가한 후, 가열하여 $\mathrm{OH}$ 부분을 $\mathrm{Br}$ 으로 전환[15]시켰다. 고체상의 생성물의 결정을 만들기 위해 냉장고 안에서 보관한 후, 생성된 고 체를 유리 필터로 걸러서 화합물 6을 60 70\% 수율로 합성하였다. ${ }^{1} \mathrm{H}$ NMR 스펙트럼에서 $3.6 \mathrm{ppm}\left(-\underline{\mathrm{CH}}_{2} \mathrm{OH}\right)$ 가 $3.4 \mathrm{ppm}\left(-\underline{\mathrm{CH}}_{2} \mathrm{Br}\right)$ 으 로 피크이동으로 생성물을 확인하였다. $\mathrm{SH}$ 기능기를 도입하기 위하 여 화합물 6 을 $95 \%$ 에탄올에 녹인 후, thiourea를 첨가[16]한 후 환 류시켜 화합물 7을 80 99\% 수율로 합성하였다. ${ }^{1} \mathrm{H} \mathrm{NMR}$ 에서 $-\underline{\mathrm{CH}}_{2} \mathrm{Br}$ 의 $3.4 \mathrm{ppm}$ 이 $-\mathrm{CH}_{2} \mathrm{SCNH}$ 의 $2.4 \mathrm{ppm}$ 으로 이동과 ${ }^{13} \mathrm{C} \mathrm{NMR}$ 스펙트 럼에서 $173 \mathrm{ppm}(-\mathrm{SCNH})$ 의 피크로 생성물을 확인하였다. 화합물 7 을 센 염기 $(\mathrm{KOH})$ 수용액을 넣어 가열하여 화합물 $\mathbf{8}$ 을 합성하였다. 그러나 물질을 분리하기 힘들기 때문에 반응이 완료된 다음, 곧바로 methylene chloride에 녹인 후, 센 산 $\left(\mathrm{H}_{2} \mathrm{SO}_{4}\right)$ 으로 처리[17]하여 목표 화합물(1a)을 70 80\% 수율로 얻었다. ${ }^{13} \mathrm{C} \mathrm{NMR}$ 에서 $173 \mathrm{ppm}(-\mathrm{SCNH})$ 의 피크가 없어지는 것으로 $\omega$-mercapto alkylamine이 합성되었음을 확인하였다.

\section{$3.2 \omega$-Mercapto alkanoic $\operatorname{acid}(2)$ 의 제조}

$\omega$-Bromoalkanoic acid를 $95 \%$ 에탄올 속에서 thiourea[16]을 넣어 환류시킨 후 재결정 방법을 이용하여 화합물 9을 69 85\% 수율로 얻 었으며 ${ }^{1} \mathrm{H} \mathrm{NMR}$ 스펙트럼에서 $3.1 \mathrm{ppm}\left(-\mathrm{CH}_{2} \mathrm{SCNH}-\right)$ 과 ${ }^{13} \mathrm{C} \mathrm{NMR}$ 에서 $176,172 \mathrm{ppm}\left(\mathrm{CO} . \mathrm{CNH}_{2}\right)$ 로 생성물을 확인하였다. 화합물 2을
합성하기 위해 화합물 9을 센 염기 $(\mathrm{KOH})$ 수용액으로 환류하여 thiuronium bromide를 제거한 다음, methylene chloride에 녹인 후, 센 산 $\left(\mathrm{H}_{2} \mathrm{SO}_{4}\right)$ 으로 처리[17]하여 두 번째 목표화합물 2를 70 80\% 수 율로 얻었다. ${ }^{1} \mathrm{H} \mathrm{NMR}$ 스펙트럼에서 $3.1 \mathrm{ppm}\left(-\mathrm{CH}_{2} \mathrm{SCNH}-\right)$ 에서 2.4 $\mathrm{ppm}\left(-\mathrm{CH}_{2} \mathrm{SH}\right.$ )로 피크가 이동하였으며, ${ }^{13} \mathrm{C} \mathrm{NMR}$ 에서 $172 \mathrm{ppm}$ 이 없 어지는 것으로 원하는 생성물질을 확인하였다.

\section{4. 결 론}

자기조립단분자막 제조를 위한 긴 사슬 알칸티올 유도체로 $\omega$ mercapto alkyl amine(1)나 $\omega$-mercapto alkanoic acid(2) 등을 5단계 와 2 단계 반응을 통하여 각각 제조하였으며, 반응의 각 단계들을 정 립하였다. 앞으로 긴 사슬 알킬티올 연결자는 단백질, 효소 및 다양 한 생체물질들 간의 분자인식(molecular recognition) 연구에 큰 역할 을 할 것으로 기대된다. 즉, 금속표면(Au, Pt, Ti)에 부착된 단분자막 을 바탕으로 특정 항원의 단분자막을 만들며, 이러한 결과들을 바탕 으로 특정 항원에 대한 항체 간의 상호 작용을 연구하는데 필수적인 기반기술로 사용될 것이며, 따라서 신약 DNA chip, protein chip 등 의 바이오 센서 분야를 선도할 수 있는 유기소재로 응용이 가능할 것 으로 예상된다.

\section{감 사}

이 논문은 지식경제부 신재생에너지기술개발사업의 일환 (2009T100100606)으로 수행되었습니다. 이 논문은 2010년도 정부 (교육과학기술부)의 재원으로 한국연구재단의 대학중점연구소지원 사업으로 수행된 연구입니다(2010-0029706).

\section{참고문헌}

1. (a) Fabianowski, W., Coyle, L. C., Weber, B. A., Granata, R. D., Castner, D. G., Sadownik, A. and Regen S. L., "Spontaneous Assembly of Phosphatidylcholine Monolayers via Chmisorption Onto Gold,' Langmuir, 5, 35-41(1989). (b) Swalen, J. D., Allara, D. L., Andrade, J. D., Chandross, E. A., Garoff, S., Israelachvili, J., McCarthy, T. J., Murray, R., Pease, R. F., Rabolf, J. F., Wynne, K. J. and Yu, H., "Molecular Monolayers and Films," Langmuir, 3, 932-950(1987).

2. Nuzzo, R. G. and Allara, D. L., "Adsorption of Bifunctional Organic Disulfides on Gold Surfaces," J. Am. Chem. Soc., 105, 4481-4483(1983).

3. Schierbaum, K. D., Weiss, T., Thoden van Vekzen, E. U., Engbersen, J. F. J., Reinhoudt, D. N. and Göpel, W., "Molecular Recognition by Self-assembled Monolayers of Cavitand Receptors,' Science, 256, 1413-1415(1994).

4. Thoden van Velden, E. U., Engbersen, J. F. J. and Reinhoudt, D. N., "Self-assembled Monolayers of Receptor Adsorbates on Gold: Preparation and Characterization,', J. Am. Chem. Soc., 116, $3597-$ 3598(1994).

5. Kim, T., Ye, Q., Sun, L., Chan, K. C. and Crooks, R. M., "Polymeric Self-assembled Monolayers. 5. Synthesis and Characterization of $\omega$-functionalized, Self-assembled Diacetylenic and Polydiacetylenic Monolayers,' Langmuir, 12, 6065-6073(1996).

6. Kim, U. R., "Applications of Self-assembled Monolayers(SAMs) for 
Biosensor,' Korean J. Biotechnol. Bioeng., 17(5), 412-428(2002).

7. Dermody, D. L., Crooks, R. M. and Kim, T., "Interactions Between Organized, Surface-confined Monolayers and Vapor-phase Probe Molecules. 11. Synthesis, Characterization, and Chemical Sensitivity of Self-assembled Polydiacetylene/calix[N]arene Bilayers,' $J$. Am. Chem. Soc., 118, 11912-11917(1996).

8. Schönherr, H., Vancso, G. J., Huisman, B.-H., van Veggel, F. C. J. M. and Reinhoudt, D. N., "An Atomic Force Microscopy Study of Self-assembled Monolayers of calix[4]resorcinarene Adsorbates on Au(111),' Langmuir, 13, 1567-1570(1997).

9. Dermody, D. L., Lee, Y., Kim, T. and Crooks, R. M., "Synthesis, Characterization, and Chemical Sensitivity of Self-assembled Bilayers Composed of Polydiacetylenes and Calix[4]arenes Chemically Modified on the Upper Rim,' Langmuir, 15, 8435-8440(1999).

10. Seo, K., Jeon, I. C. and Yoo, D. J., "Electrochemical Characteristics of Ferrocenecarboxylate-coupled aminoundecylthiol selfassembled monolayers,' Langmuir, 20, 4147-4154(2004).

11. Yao, H., Kojima, H., Sato, S. and Kimura, K., "Interparticle
Spacing Control in the Superlattices of Carboxylic Acid-capped Gold Nanoparticles by Hydrogen-bonding Mediation,' Langmuir, 20, 10317-10323(2004).

12. Kazemekaite, M., Bulovas, A., Talaikyte, Z., Railaite, V. and Niaura, G., Tetrahedron Lett., 49, 6212-6216(2008).

13. Armerigo, W. L. F. and Perrin, D. D. Purification of Laboratory Chemicals, 4th Ed.; Oxford: Butterworth-Heinemann, 1996.

14. Smith, L. I. and Emerson, O. H., "tert-Butylphthalimide", Organic Syntheses, 3, 151-153(1955).

15. Cortest, F., " $\beta$-Bromoethylamine Hydrobromide,' Organic Syntheses, 2, 91-93(1943).

16. Miller, G., Cuendet, P. and Grätzel, M., "Adsorbed $\omega$-hydroxy Thiol Monolayers on Gold Electrodes: Evidence for Electron Tunneling to Redox Species in Solution,' J. Phys. Chem. 95, 877-886 (1991).

17. John Speziale, A., "Ethanedithiol,' Organic Syntheses, 4, 401-403 (1963). 